\title{
Journal News: Osmar Pinto Jr. et al.'s Research Work, Published in American Journal of Climate Change, Has Been Reported by BBC News
}

\author{
AJCC Editorial Board
}

Copyright (C) 2014 by authors and Scientific Research Publishing Inc.

This work is licensed under the Creative Commons Attribution International License (CC BY). http://creativecommons.org/licenses/by/4.0/

\section{(c) (i) Open Access}

The city of Manaus (Brazil) is located in the central part of the largest tropical forest in the world, the Amazon rainforest, and has a population of approximately 2 million inhabitants. Osmar Pinto Jr., Iara Regina Cardoso de Almeida Pinto, and Osmar P. Neto showed that the lightning activity in Manaus is larger than that in the regions around the city and it has been increasing in the last four decades with the increasing of the urban area of the city. These results suggest that these spatial and time variations are related to the Urban Heat Island effect, since it is believed that the Urban Heat Island effect influences thunderstorm formation and evolution and, in consequence, the lightning activity. Therefore, they suggest that the replacement of the forest by urban areas tends to increase the lightning activity in the Amazon region. These results were published in American Journal of Climate Change in December 2013 [1].

In March 14, 2014, BBC News reported Osmar Pinto Jr. et al.'s results. The title of news report is "Enlightened forest”, in detail, please find at http://www.bbc.com/news/science-environment-26554974.

\section{References}

[1] Pinto Jr., O., Pinto, I. and Neto, O. (2013) Lightning Enhancement in the Amazon Region Due to Urban Activity. American Journal of Climate Change, 2, 270-274. http://dx.doi.org/10.4236/ajcc.2013.24026 
Scientific Research Publishing (SCIRP) is one of the largest Open Access journal publishers. It is currently publishing more than 200 open access, online, peer-reviewed journals covering a wide range of academic disciplines. SCIRP serves the worldwide academic communities and contributes to the progress and application of science with its publication.

Other selected journals from SCIRP are listed as below. Submit your manuscript to us via either submit@scirp.org or Online Submission Portal.
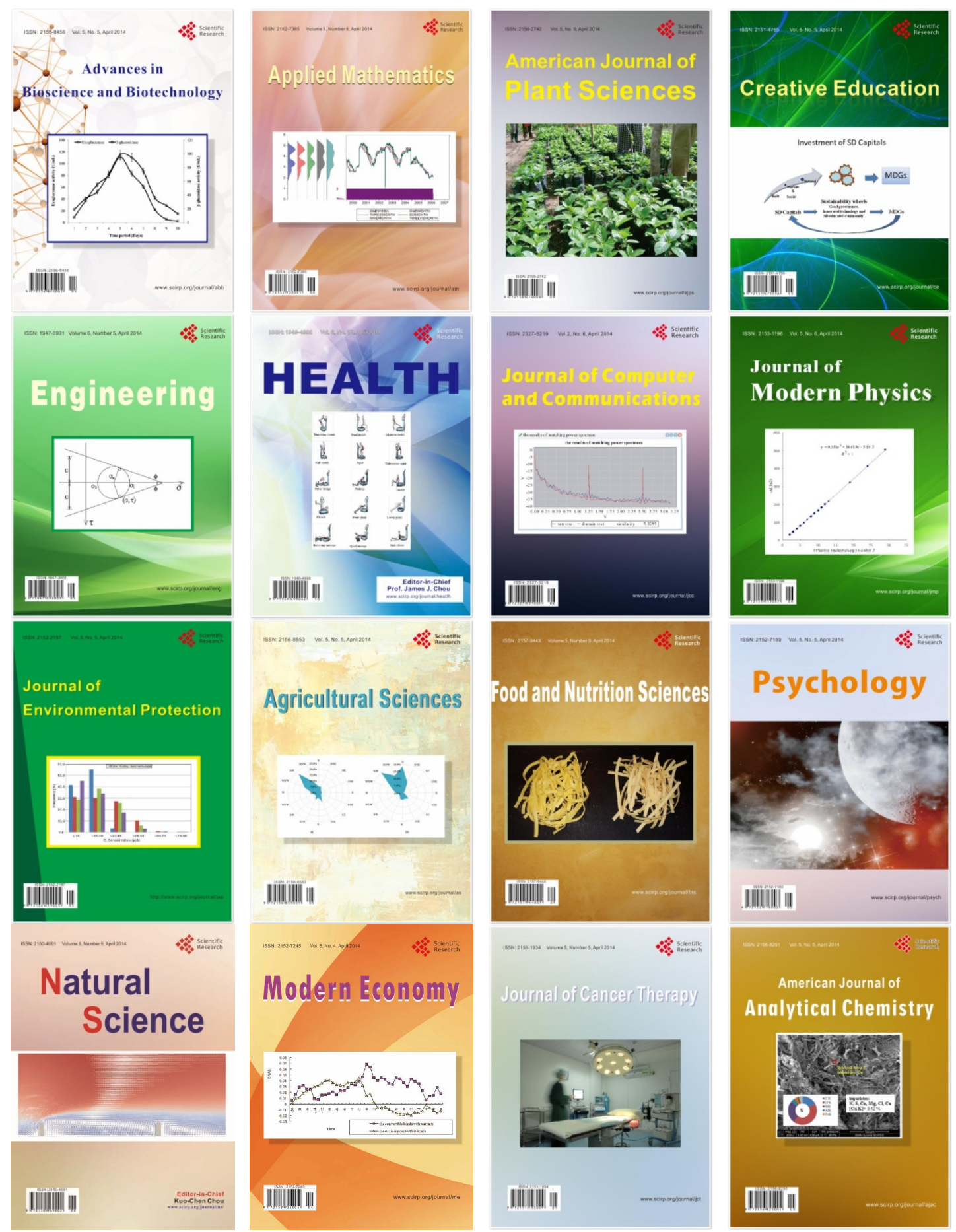